\title{
Saving Indonesia's Golden Generation: Preventing Teenage Marriage in Rembang, Central Java (A Case Study)
}

\author{
Partini \\ Department of Sociology, Faculty of Social and Political Sciences, Universitas Gadjah Mada, \\ Indonesia
}

\author{
Hermin Indah Wahyuni \\ Department of Communication Sciences, Faculty of Social and Political Sciences, Universitas \\ Gadjah Mada, Indonesia
}

\author{
Lidwina Mutia Sadasri* \\ Department of Communication Sciences, Faculty of Social and Political Sciences, Universitas \\ Gadjah Mada, Indonesia
}

\begin{abstract}
Indonesia is expected to reap the benefits of a golden generation, enjoying an advanced and independent modern society in the year of 2045 . However, there are great challenges ahead including problems amongst younger Indonesians which may hinder the realization of this projection. This study brings to the fore the problem of teenage marriage, defined as the marriage of two individuals under the age of eighteen, be it through coercion or through their own volition. Data show that $14.18 \%$ of married Indonesian women are younger than 16 years old (SUSENAS, 2017); with 1.459,000 teenage girls marrying per annum so that the country ranks eighth globally in terms of teenage marriage (UNICEF, 2020). Using a cybernetics communication approach and qualitative method, this article assesses teenage marriage prevention programs in Rembang, a regency in middle Java, Indonesia. This study found that prevention of teenage marriage is not part of everyday discussion in the grassroots. Public discourse has stalled at the information stage, optimal understanding has yet to be realized. With this backdrop, Rembang regency utilize a topdown approach in organizing its teenage marriage prevention programs. However, synergy and cooperation remain necessary to minimize the practice by maximizing collaboration with families, schools, health officials, religious officials, and civil servants who turn to be the most influential actors in such programs.
\end{abstract}

Keywords: child marriage; teenage marriage; Indonesia; cybernetics

\section{Introduction}

Teenage marriage remains a severe problem in Indonesia, as recent data show that such marriages continue to occur in alarming numbers. The Indonesian Demographic and Health Survey (IDHS),

Corresponding email: lidwina.mutia@ugm.ac.id 
conducted in 2012, found that $17 \%$ of married Indonesian women (age 20-24) were married before the age of 18. In 2016, katadata.co.id reported that one in nine Indonesian women married under the age of 18. Data from the 2017 National Social and Economic Survey (Susenas) noted that 14.18 per cent of married women in Indonesia were younger than 16 years old.

This research focuses on discourse about teenage marriage in Indonesian media. It will focus primarily on new media and, more specifically, on the sociological context in which society responds to this problem. Therefore, it employs a cybernetics approach to analyse teenage marriage. Of the seven traditions in communication science, cybernetics best appreciates the complexity of communication problems and questions the differences of various information processing systems. In this context, the problem of teenage marriage is identified as "information," which is processed in a specific manner by the local communication system. In this case, the local communication system (the object of study) is directly related to how the local sociological and cultural systems have responded to the problem of teenage marriage.

Indonesia, as the locus and context of this study, will first be described, followed by Rembang Regency, Central Java, a region where teenage marriage remains prevalent. These macro- and microenvironments are inexorably related, with the macro-environment offering a measure of Indonesians' knowledge of teenage marriage and discourse on the subject. Using Rembang as a case study, this study seeks to examine the communication system for preventing teenage marriage in Indonesia by answering three research questions: (1) How is the issue of child marriage discussed in Indonesian society? (2) How have communication systems in areas with high teenage marriage rates (i.e. Rembang) developed to respond to this major issue? (3) Are existing communication systems capable of encouraging change and reducing the prevalence of teenage marriage?

Given that teenage marriage has drawn the concern of the general public, it has been widely discussed from various perspectives. Most studies have taken a cultural or sociological approach. This study, however, employs a communication approach to provide a fresh perspective on teenage marriage and its sociological elements. In the cybernetics tradition, this article is expected to encourage broader discussion about teenage marriage as an essential issue in Indonesian society, with improved communication being expected to encourage further discussion and more comprehensive explanations of this issue.

\section{Literature Review}

\section{Cybernetic Perspective in Communication: Feedback and Autopoietic Mechanism}

In the cybernetics tradition, communication studies are understood as involving such diverse elements as information science, cognition and artificial intelligence, functional social theory, network analysis, and interpersonal communication (Watzlawick, Beavin \& Jackson, 1967). In the cybernetics tradition, communication is theorised as information processing, and thus as explaining all complex systems: alive or dead, macro or micro, functioning or malfunctioning. Cybernetics sees communication problems as emerging from issues in the flow of information, be it due to interference, overload, or incompatibility, and thus refers to these elements to solve communication problems. According to Geoghean, cybernetics and information analysis relies on such keywords as encoding, decoding, signal, feedback, entropy, equilibrium, information, communication, control, all of which sustain the analogies between these ontologically distinct classes. At more complex levels, the cybernetic tradition (Littlejohn \& Foss, 2009) consists of feedback, information, self-reference, recursive computation, self-organisation, autopoiesis, cognitive autonomy, participatory epistemology, language and discourse.

This paper will draw on two main concepts: feedback and autopoietic mechanism. Feedback is based on one's ability to manage environmental information through a cyclic series of communication 
behaviours that serve to reduce equivocality: action, response, and adjustment. Action refers to behaviour that indicates equivocality in a person, institution, or social system's receipt of a message; response refers to reactions to this equivocality; and adjustment refers to organisational responses to equivocality (West and Turner, 2010). In this study, the intended feedback refers to the feedback of the Indonesian social system, especially in Rembang (the case study area), as well as its equivocal response to the problem of teenage marriage.

The autopoietic mechanism, meanwhile, is described in the spirit of self-reference or selforientation. The concept of self-reference is crucial in cybernetics, as each system is expected to develop itself based on its own needs and the input it receives. It fundamentally involves collecting input from the system itself and responding based on its elements. Autopoiesis, thus, is the logic of self-reference in communication. As stated by Luhmann, "only communication can influence, break down, control, and repair communication" (Ritzer, 2004).

Luhmann identifies communication as consisting of three components: information, utterance, and understanding. "Successful" communication is communication that is carried out by the system, produces elements of the (communication) system, and is "called" again for subsequent communication. By linking previous and subsequent communication, the system develops its structure through a process of self-organization (Luhmann, 1995). Through the selection of information, expressions, and understandings, and as limited by prior communication, current communication provides limits for future communication (Luhmann, 1995, Ritzer, 2004). In this study, discussion of teenage marriage is considered communication regarding this central issue, and the quality of this communication will be evaluated to determine whether it can promote the prevention of teenage marriage.

Although Luhmann argues that all systems (political, economic, social, cultural, etc.) are world systems, and thus have the same elements for specific types of systems, they may differ in their sensitivity and response to the outside environment. In the context of self-reference, it is interesting to see how (for example) local communication systems throughout Indonesia have developed different responses to the problem of teenage marriage.

\section{Local Communication Systems and their Responses to Teenage Marriage}

Child, Early, and Forced Marriage (CEFM), referred herein as teenage marriage, is a complex issue, being influenced by-and influencing-the social and economic conditions of a given national context, as well as cultural, social, and religious attitudes towards sexuality, gender roles, and the appropriate age for childbearing. It is estimated that, if this type of violence against children continues at its current rate, approximately 320 million girls will be at risk of teenage marriage by 2050; over 18 million girls a year will be married before the age of 18 . Almost all countries have some form of law in place to protect girls from teenage marriage, and yet the practice is prevalent throughout these countries.

According to Jordana (n.d.), there must be better engagement in challenging people's attitudes both regarding the status of women/girls and the practice of teenage marriage. Without grassroots engagement, little will change. Various preventative efforts have thus been undertaken to prevent teenage marriage, particularly given its deleterious social, economic, and health effects. Many countries have worked with non-governmental organisations to implement preventative measures. Those described in this section were implemented in South, Southeast, and East Asia (See Center for Reproductive Rights, 2014; Plan Asia, 2013, Malhotra et. al., 2011, ASEAN, 2017, and Lee-Rife et al., 2012).

In South Asia, teenage marriages are common, and rates are the second-highest in the world (behind only West Africa). Such marriages are typically performed in accordance with the religious customs and traditions of the involved parties. In most South Asian countries, personal laws set specific 
age requirements for marriage, with reflection on specific religious teachings. Such personal laws (except in Nepal, which was never colonized by a foreign power) can be tracked back to colonial governments, which conceded the regulation of family issues and property rights as a means to negotiate for broader legal reforms (Centre for Reproductive Rights, 2014). Given the diversity of South Asia, preventative strategies must be developed that accommodate the specific characteristics of communities and countries.

The Plan Asia Teen Marriage Initiative (ACMI), for instance, is a multi-country initiative started in 2010 that aims to prevent teenage marriage and mitigate its negative consequences by understanding its practice and exploring pathways for addressing the issue (Plan Asia, 2013). It employs different prevention approaches in different countries. For example, in Bangladesh, Plan Asia aims to increase the mean age of marriage from 15 to 18 years and works with the national government to improve the online registration of births and to enforce the Teen Marriage Restraint Act of 1929. In India, Plan Asia's goal is to improve knowledge, attitudes, and practices regarding teenage marriage and track the prevalence of the practice. In Nepal, meanwhile, Plan Asia sees teenage marriage as an aspect of genderbased violence and aims to build the capacity and commitment of teen, their families, and communities to eliminate the practice (Plan Asia, 2013).

As for Southeast Asia, in 2013, the Heads of State of the Association of Southeast Asian Nations (ASEAN) signed the Declaration on the Elimination of Violence Against Children in ASEAN. In 2016, the ASEAN Regional Plan of Action on the Elimination of Violence Against Children (RPA-EVAC) came into force, setting out Member States' commitments to protecting children (including teenagers) from violence and responding to their needs across twelve key priority areas: non-violent child nurturing, awareness-raising campaigns on all forms of violence against children, alternative family care services, preventive measures against violence in cyberspace, child- and gender-sensitive reporting and complaint mechanism, robust protective and supportive services for teen affected by violence, legislative review on violence against children and teenagers (raising the minimum age of marriage for both girls and boys to 18), legislative and/or policy frameworks for diversion and alternatives to detention, advocacy materials on violence against children and teenagers, disaggregated survey data on violence against children and teenagers, national action plans, and responses to violence against children and teenagers in disaster- and conflict-afflicted areas (ASEAN, 2017). Several priority programmes offered by RPA-EVAC further show the significance of the study of teen marriage prevention to be prioritized in Indonesia, which has a high rate of teen marriage.

Meanwhile, the International Center for Research on Women (ICRW) conducted a systematic review of evidence-based programmes around the world and found that the majority of programmes in Asia use several primary strategies: (1) empowering girls with information, skills, and support, (2) educating and mobilizing parents and community members, (3) enhancing the accessibility and quality of formal schooling for girls, (4) offering economic support and incentives for girls and their families, (5) fostering and enabling legal and policy framework (Malhotra et al., 2011). Lee-Rife et al. (2012) reviewed 23 teen marriage prevention programmes in low-income countries, finding that they employ a range of programmatic approaches and evaluation strategies. The evidence suggests that programmes offering incentives and attempting to empower girls can be useful in preventing teenage marriage and can foster change relatively quickly.

This general overview of teenage marriage prevention programmes provides a basis for comparison, which shows the significance of the current study in Indonesia. Given that, in Indonesian society, reproductive health is generally regarded as a private or even taboo matter, discourse regarding teenage marriage has been limited even as the practice of child marriage in Indonesia has continued. This study is thus particularly significant. 


\section{Methods}

This study, in accordance with its research object and questions, employs a case study approach. According to Soy (2006), this approach can provide a good understanding of complex issues and subjects, and can expand the experiences and understandings of previous research. This method emphasizes a detailed and contextual analysis of a limited number of events, or conditions related to them, and the relationships intertwined therein. Case studies may be exploratory, explanatory, or descriptive (Yin, 2003), and may use data from six sources: direct observation, interviews, notes, documents, participant observation, and physical artifacts (Yin, 2012). In this study, given the relevance and reference of the research problem, data were only collected through some of these techniques. Observations were conducted at the Rembang Office of Religious Affairs and the Rembang Office of Social Affairs, and interviews were conducted with respondents from these offices as well as local NGO activists, village chiefs, and teenagers. Research was further supported by data from related agencies.

Using the concepts of cybernetic communication and local communication systems, this research seeks to analyse the programmes implemented in Rembang, Central Java, in order to prevent teenage marriage. It seeks to answer questions about how systems in areas with high rates of teenage marriage respond to such problems, as well as ascertain whether existing communication systems can curtail the practice of teenage marriage.

Data analysis was conducted using the research process offered by Miles, Huberman, and Saldana (2014), and involved three activities: data condensation, data display, and conclusion drawing/verification. Data condensation refers to the process of selecting, focusing, simplifying, abstracting, and transforming data from the full corpus of collected materials (as incorporated in field notes, interview transcripts, documents, etc.). Data display refers to the organised, compressed assembly of information that allows conclusion drawing and action. Conclusions drawn by the researchers are verified through subsequent analysis.

\section{Results and Discussion}

\section{Social Communication Regarding Teenage Marriage}

Communication media is one platform that may be used to "read" the social situation, as through the media all kinds of issues-especially those related to the public interest, or expected to be of public interest-become prominent in society. Through various communication media, including new media and the internet, the Indonesian public can obtain information regarding the practice and prevalence of teenage marriage.

Through Google and Yahoo Search, and using various keywords, the research team made several inquiries into the practice of teenage marriage. One inquiry, conducted on May 31, 2018, using Google Search with the keyword "child marriage", returned 58,400,000 findings in 0.40 seconds; an inquiry using Yahoo Search with the same keyword returned 3,970,000 findings (Wahyuni, et. al., 2018). The online media returned through these inquiries, including a number of viral media content regarding children who were forced into an early marriage without consideration of their futures or reproductive health, showed that child and teenage marriage are empirically present in society and are strongly influenced by sociological and cultural factors. Indeed, these inquiries found that proponents of teenage marriage have become more prominent than its opponents. Social movements that encourage teenage marriages, such as hashtag \#NikahMuda, \#MarriedYoung, and \#Indonesiatanpapacaran, have become increasingly institutionalised; in 2018, these movements have 900,000 followers on Facebook and 400,000 followers on Instagram (BBC News, 2018). 
Wahyuni et al. (2018) also made several findings about teenage marriage content on Facebook and Twitter. An IPA analysis of Facebook and Twitter content published between December 2017 and May 2018 found that the most widely disseminated and discussed content was a story about the marriage of a junior high school student in Sulawesi. Remarks and comments were predominantly positive, with many viewing the relationship within the context of reproduction.

From this review of the literature, it can be seen that the issue of teenage marriage has received significant discourse. However, it seems that said discourse has not been able to encourage an optimal of the issue. Referring to Luhmann's concepts of information, utterance, and understanding, the communication is of insufficient quality to achieve optimal understanding. At the discourse level, there is even strong competition between proponents and opponents of teenage marriage, with viral cases of early marriage continuing to colour the discourse. It can be said that differentiation in the social system is still lacking, a finding that strengthens the initial assumption that teenage marriage is an "iceberg" phenomenon, one that evident on the surface but whose roots remain hidden.

\section{Teenage Marriage Prevention in Rembang}

Recognising that the Rembang Regency government has received several awards for its efforts to prevent teenage marriage, a practice that has been labelled traditional (2013). this location was chosen as the locus of the study. Of Rembang's fourteen districts-Bulu, Gunem, Kaliori, Kragan, Lasem, Pamotan, Pancur, Rembang, Sale, Sarang 1, Sarang 2, Sedan, Sluke, Sulang, and Sumber-five had been chosen for PLAN Indonesia's Child-Friendly Regency/"Kabupaten Layak Anak" programme. In each of these districts, six villages received assistance in reducing teenage marriage.

The below data on teenage marriage in Rembang (2013-2017) was received from H. Moh. Mukson, the Acting Director for Islamic Community Guidance at the Rembang Office of Religious Affairs, in April 2018.

Table 1. Marriage by Age in Rembang, 2013 to 2017

\begin{tabular}{|c|c|c|c|c|c|c|c|c|c|c|}
\hline \multirow[t]{3}{*}{ Age } & \multicolumn{10}{|l|}{ Year } \\
\hline & \multicolumn{2}{|l|}{2013} & \multicolumn{2}{|l|}{2014} & \multicolumn{2}{|l|}{2015} & \multicolumn{2}{|c|}{2016} & \multicolumn{2}{|l|}{2017} \\
\hline & $\mathrm{M}$ & $F$ & $\mathrm{M}$ & $\mathrm{F}$ & $\mathrm{M}$ & $F$ & $\mathrm{M}$ & $\mathrm{F}$ & $\mathrm{M}$ & $F$ \\
\hline $10-16$ & 0 & 26 & 0 & 33 & 0 & 47 & 0 & 35 & 0 & 31 \\
\hline $17-18$ & 26 & 1643 & 44 & 1183 & 23 & 1463 & 18 & 1541 & 23 & 1220 \\
\hline 19-25 & 2246 & 2648 & 2051 & 2547 & 2171 & 2190 & 2166 & 2228 & 1853 & 2020 \\
\hline $26-30$ & 2273 & 867 & 2166 & 974 & 1657 & 632 & 1706 & 695 & 1494 & 642 \\
\hline $31-35$ & 1405 & 702 & 1281 & 832 & 656 & 262 & 593 & 244 & 603 & 275 \\
\hline $36+$ & 0 & 0 & 70 & 19 & 563 & 349 & 590 & 301 & 620 & 405 \\
\hline
\end{tabular}

Note: M (Male), F(Female).

(Rembang Office of Religious Affairs, 2017)

Sedan District has a relatively high number of teenage marriages, with 500 couples being married in one year; on average, $5 \%$ of newlyweds are below the age of eighteen. Interviews conducted in Rembang confirmed the "Yes I Do" Alliance's argument that teenage brides are severely affected by their age. In one interview, the bride responded emotionally, saying, "Anyway, I am happy with A. I do not want to be separated. If I were not (married), I would kill myself."

The high prevalence of teenage marriage in Sedan can be attributed to several factors. First, as highlighted by the Office of Religious Affairs (Sedan District), such marriages are significantly affected 
by parents' education, awareness, social status, and economic status. On average, parents in Sedan lack knowledge about marriage, and feel happier if their daughters marry sooner. When a school-age girl receives a marriage proposal, she is expected to leave school and marry, thereby alleviating her parents' economic burdens. This, together with religious beliefs, has resulted in early marriage becoming common. Parents in Rembang prefer to have pious children (and children-in-law) who can read the Holy Qur'an fluently; as such, many send their children to pesantren (Islamic boarding schools) for their education.

Difficulty attending school is another factor that promotes teenage marriage. Although they attend school, they are not yet at a conscious stage of learning. In the case of Sedan, teenagers gain an awareness of the need for education not on their own, but by seeing peers and neighbours attend school. Data collected at the Rembang Office of Religious Affairs indicated that several efforts have been made to socialise anti-teenage marriage programmes at the district level, meeting with village heads, coordinating with communities, and inviting teenagers to the office.

Working with the Office of Education and Culture, the Office of Religious Affairs has provided university scholarships to underprivileged students in order to reduce the number of teenage marriages. Meanwhile, working with the Ministry of Health (through district-level clinics and village midwives), the Office of Religious Affairs has sought to educate villagers about reproductive health. In 2011 and 2018, Rembang received national awards for its anti-teenage marriage programmes, even as the practice remained prevalent; such awards were intended to recognise the local government's efforts to work with village governments in overcoming teenage marriage.

The Office of Social Affairs has also implemented efforts to utilise tertiary institutions as educational spaces for Rembang teenagers. In this, it has involved such institutions as STIE YPPI Rembang, the State Community Academy, and the Indonesian Community Academy (AKSI).

Early marriage in Rembang has been motivated by several factors. Many families resort to teenage marriage as a means of improving families' economies. When research was conducted in 2018, Rembang's poverty rate was relatively high (18\%). Although the Regent sought to reduce unemployment to $11 \%$, this was challenging. Efforts are focused on villages that remain in red status (in terms of poverty, education, and health), representing 75 of the 287 villages in the regency.

Early marriage in Rembang has been motivated by several factors. Many families resort to teenage marriage as a means of improving families' economies. When research was conducted in 2018, Rembang's poverty rate was relatively high (18\%). Although the Regent sought to reduce unemployment to $11 \%$, this was challenging. Efforts are focused on villages that remain in red status (in terms of poverty, education, and health), representing 75 of the 287 villages in the regency.

Another factor that contributes to the practice of teenage marriage is religion. However, emphasis is given not to preventing fornication, but rather a highly textual interpretation of religious texts. There are also cultural factors; in Rembang, it is believed that if parents refuse a marriage proposal, their daughter will have difficulty finding a spouse in the future. As such, parents are incentivised to remove their children from school. Early marriages may also be driven by teenagers not wanting to attend school, not being allowed to attend school, or becoming pregnant unexpectedly.

Prevention programmes have been implemented both by the government and by NGOs. The government, for example, has provided specific information on the risks of early marriage to teenagers who apply for permission to marry before achieving the legal minimum. The Village Teen Forum (FORMAD), meanwhile, has sought to ensure that teenagers are actively involved in discussions of such issues as puberty, reproductive health, the risks of early marriage, healthcare, and the human body. Teenagers are also involved in activities to develop their capacities and their understandings of their rights and obligations, as well as to socialise safe internet usage habits. Parents are provided modules that outline the rights of teenagers and the risks of early marriage. Economic empowerment and 
education activities, including soft skills training for entrepreneurs (teaching them to produce banana ice cream, instant corn meal, chips, keychains, etc.), are also used as a means of indirectly preventing teenage marriage.

Table 2. Marriage Data, Rembang, January-October 2019

\begin{tabular}{|c|c|c|c|c|c|c|}
\hline \multirow[t]{3}{*}{ No. } & \multirow[t]{3}{*}{ Office } & \multirow{3}{*}{$\begin{array}{l}\text { Number of } \\
\text { marriages }\end{array}$} & \multicolumn{4}{|l|}{ Age } \\
\hline & & & \multicolumn{2}{|c|}{ Male } & \multicolumn{2}{|c|}{ Female } \\
\hline & & & -19 & $19-21$ & -16 & $16-21$ \\
\hline 1. & Bulu & 184 & 0 & 26 & 6 & 62 \\
\hline 2. & Gunem & 165 & 0 & 41 & 0 & 77 \\
\hline 3. & Kaliori & 282 & 1 & 28 & 0 & 95 \\
\hline 4. & Kragan & 364 & 4 & 48 & 5 & 143 \\
\hline 5. & Lasem & 319 & 0 & 3 & 0 & 56 \\
\hline 6. & Pamotan & 338 & 1 & 19 & 0 & 135 \\
\hline 7. & Pancur & 188 & 0 & 8 & 0 & 64 \\
\hline 8. & Rembang & 561 & 5 & 27 & 2 & 119 \\
\hline 9. & Sale & 270 & 1 & 43 & 0 & 125 \\
\hline 10. & Sarang 1 & 254 & 0 & 22 & 1 & 116 \\
\hline 11. & Sarang 2 & 141 & 0 & 13 & 0 & 57 \\
\hline 12. & Sedan & 402 & 0 & 58 & 0 & 193 \\
\hline 13. & Sluke & 179 & 1 & 6 & 0 & 71 \\
\hline 14. & Sulang & 271 & 1 & 31 & 2 & 84 \\
\hline 15. & Sumber & 258 & 2 & 35 & 0 & 108 \\
\hline \multicolumn{2}{|l|}{ Total } & 4.176 & 16 & 408 & 16 & 1505 \\
\hline
\end{tabular}

(Rembang Office of Religious Affairs, 2017)

Only five of Rembang's fourteen districts were included in PLAN Indonesia's pilot project, and even then, only six villages in each district (for a total of thirty villages altogether) receive assistance. Villages were chosen in recognition of the prevalence of teenage marriage, as driven by religious values and patriarchal culture. As part of this programme, PLAN established Village Teen Forums that work in conjunction with village chiefs to curtail teenagers' desire for marriage.

The Rembang government had implemented multiple policies between 2008 and 2017 to tackle the problems of women and children (including teenagers), namely:

a. Rembang Regent Regulation No. 29/2008 concerning Integrating Services for Victims of Violence against Women and Children

b. Rembang Regent Regulation No. 30/2009 concerning Child-Friendly District Policy and ChildFriendly Villages

c. Decree of the Regent of Rembang No. 411.4/984/2010 concerning Youth Information and Counselling Centres

d. Rembang Regulation No. 19/2010 concerning the Action Plan for the Elimination of the Worst Forms of Teen Labour in Rembang District

e. Rembang Decree No. 22/2010 concerning the Regional Action Plan for Rembang

f. Decree of the Regent of Rembang No. 050/531/2010 concerning the Establishment of ChildFriendly Villages in Rembang District

g. Rembang Regent Regulation No. 0411/2011 concerning the Alleviation of Maternal and Infant Mortality 
h. Decree of the Regent of Rembang No. 050/0597/2013 concerning the Secretariat and Coordination Team of the Teenager Task Force

i. Decree of the Regent of Rembang No. 050/782/2017 concerning the Gender Mainstreaming Working Group in Rembang Regency

j. Decree of the Regent of Rembang No. 050/620/2017 concerning the Appointment of Members of the Teenager Task Force

k. Regional Regulation No. 6/2017 concerning the Protection of Teenagers in Rembang Regency

Under the umbrella theme of protecting children, Rembang has already implemented several specific themes at the village level. Kutoarjo Village, for instance, has focused on children with special needs, seeking to ensure that they are valued and protected in the community. Similarly, Magersari Village has taken the theme of teenage delinquency.

Efforts to protect teenagers have also involved the signing of Memoranda of Understanding between regency-level stakeholders. For example, the Office of Religious Affairs has worked with the Office of Education and Culture to provide scholarships to vulnerable teenagers). up to the higher education. Similarly, it has worked with the Office of Health to improve public understandings of reproductive health through government-run clinics (at the district level) and midwives (at the village level). Youth counselling information centres have also been instituted to provide teenagers with information about early marriage, HIV/AIDS, and narcotics.

Several programmes have also involved collaboration between national organisations and local ones. For example, Village Teen Forums have been used to implement the Ministry of Women's Empowerment and Child Protection's Age of Majority programme. Similarly, youth counselling information centres have worked with the National Population and Family Planning Agency.

Rembang Regency received national awards in 2011 and 2018. Although teenage marriage rates remain high, stakeholders have been strongly committed and regional leaders have been supportive of programmes against early marriage. The Regent, for instance, has supported the establishment of scholarships for vulnerable teenagers.

However, as mentioned previously, this has not had a significant effect on the prevalence of teenage marriage. In 2017, for instance, 56 dispensations were issued for early marriage; only four were revoked and cancelled. Efforts have been made to improve this situation. Counsellors, from a wide range of backgrounds, are appointed by degree and serve on a volunteer basis. Although they meet only once every three months, they may use WhatsApp to discuss new and ongoing problems as well as to share news. Facilitators are available in each district. At the village level, these facilitators are integrated into Family Welfare Units (PKK), and are supervised by these units' heads. Programmes are also coordinated with Commission D of the Regional House of Representatives.

Synergy is also seen in several programmes. One regent, a religious leader who had previously served as deputy regent, was very committed to the prevention. This was demonstrated, for instance, in the Sedan Expo as well as the creation of youth clinics. With the end of the PLAN programme in 2016, the regency government has implemented the "Yes I Do" Alliance, which is chaired by the regent's wife. Similarly, the National Population and Family Planning Agency has used the Indonesian Family Planning Association (PKBI) to protect teenagers and prevent teenage marriage.

Interviews with Woro Village officials found that various activities have been employed to prevent teenage marriage. Initially, Woro Village was a PLAN-assisted area, with the theme of "protection"; in this, it sought to prevent violence and teenage labour. Under the "Yes I Do" programme, it has focused on three issues: teenagers, teenage marriage, and female circumcision. 
Currently, the Village Teen Protection Group (KPAD) - at the vanguard of teenage marriage prevention programmes-envisions making Woro a youth-friendly village. As such, it focuses on educating teenagers about their rights, about violence, aboutthe perils of juvenile delinquency, etc.

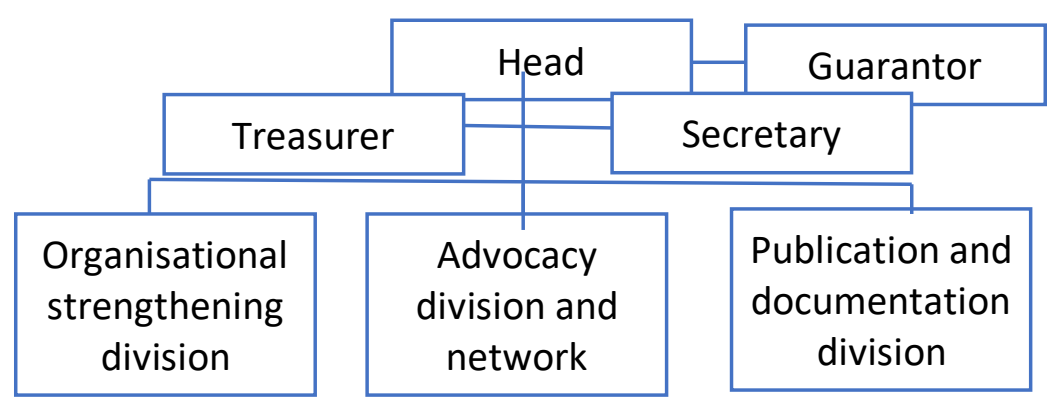

Picture 3. Institutional Structure of KPAD/KPAK

(Researchers documentation, 2018)

PLAN's assistance ended in 2016. Nonetheless, the Rembang Regency government has attempted to replicate the programmes throughout the regency. Several creative performances have been staged since 2016. Data from the Village Teen Protection Group of Woro indicates that these efforts have helped curtail teenage marriage; the number of cases decreased from 14 in 2016 to 7 in 2017 and 1 in 2018.

Woro village also has a forum for teenagers that is used to socialise teenage marriage and its perils. This programme has been considered successful; members attend school and participate in activities diligently, and thus they often invite their peers to participate.

Funding for such programmes has been varied. Before the passage of the Village Law, programmes were funded through dues (dana jimpitan) collected from the community ( $\mathrm{Rp} 200.00$ per family). Once village funds became available in 2015, KPAD was allocated $R p 4,000,000.00$. This has increased over time, from $\operatorname{Rp}$ 6,000,000.00 in 2016 to Rp 18,000,000.00 in 2017 and Rp 23,000,000.00 in 2018. Funds were used to cover six activities: routine meetings, coordination with local forums, socialisation of anti-bullying programmes, data collection, and the establishment of integrated service posts for and by village youth.

\section{Discussion}

In Rembang, the causes of teenage marriage are similar to those in other parts of Indonesia. Poverty, culture, religious conservatism, education, and teenagers' personal desires all contribute to the prevalence of this practice. Such factors have been identified previously; it is new perspectives and analyses that are needed to discuss teenage marriage.

This study, thus, has expanded the context of teenage marriage by mapping out areas that have sought (sometimes successfully) to eradicate its practice. Teenage marriage, defined as marriage before the age of eighteen, can also be understood as early marriage where the couple is still relatively young and lacks the mental, physical, and fiscal readiness for marriage.

As such, the novelty of this research lies in its analysis, which focuses on the function and role of family, society, culture, and media, all of which can perpetuate the practice of teenage marriage or reduce its prevalence. In the case of Rembang, Central Java, the practice of teenage marriage remains common in part due to teenagers' and parents' limited knowledge, and in part due to unplanned pregnancies. 
Social awareness of teenage marriage is limited, particularly in rural areas. Many Indonesians are unaware of the dangers of teenage marriage. Parents are likely to urge their daughters to get married, especially if these teenagers commonly fraternise with boys. Even if these teenagers are underage, they can easily apply for a dispensation, which is granted more often than not.

Nonetheless, such marriages are problematic. Observations and in-depth interviews with community members and officials indicated that teenage brides are in a precarious position. Pregnancy and childbirth are particularly dangerous for them, as their bodies are not yet fully developed. They are also more likely to experience issues, up to and including domestic violence, that lead to divorce.

Sociologically, teenagers are shaped and controlled by their social environment. This study emphasises the importance of the nuclear family (father, mother, and teenager). As it is becoming increasingly difficult to ensure that families' needs are met, income-once solely earned by the husband-must now be earned by both parents. Mothers must work outside the household, and thus they have less time and energy to raise their children and to maintain the household. However, even as social roles have been shifting, the dominant patriarchal culture has maintained gender inequality. Women experience a double burden, being expected to serve simultaneously as breadwinners and as caregivers. This division of labour is suboptimal. In such a situation, it is necessary to improve teenagers' knowledge and understanding of reproductive health.

\section{Conclusion}

This study has found that various programmes have been implemented to prevent teenage marriage. However, synergy and cooperation remain necessary to eradicate the practice. Data collected in the field indicates that families, schools, health officials, religious officials, and civil servants are amongst the most influential actors in such programmes, and as such they must be integrated into communication efforts.

In detail, Rembang Regency has used institutional processes to prevent teenage marriage. Government regulations have set specific guidelines for teenage marriage prevention programmes. Furthermore, it has been found that collaborative programmes (such as those implemented by the Office of Religious Affairs and the Office of Social Affairs) offer an effective means to socialise the perils of teenage marriage to both teenagers and their parents.

\section{References}

ASEAN. (2017). Ending violence against teens in ASEAN member states. Baseline study of priority areas under the ASEAN Regional Plan of Action on the Elimination of Violence Against Children: A snapshot as of 2016. Jakarta, ASEAN. Retrieved from https://www.unicef.org/Ending_violence_against_children_in_ASEAN_Member_States.p df

Center for Reproductive Rights. (2014). Teen marriage and personal laws in South Asia. New York, Center for Reproductive Rights.

IDHS. (2013). Survei demografi dan kesehatan Indonesia. ICF, Indonesia. Retrieved from https://www.reproductiverights.org/sites/crr.civicactions.net/files/documents/ChildMarriage PersonalLaw_7.7.14.pdf

Jordana, A. D. (n.d.). Situational analysis on the teen, early, and forced marriage in Vietnam, Laos, Myanmar, and Cambodia. World Vision. Retrieved from 
https://www.wvi.org/sites/default/files/report_SituationalanalysisCEFMVietnamLaosMyanmar andCambodia-FINAL.docx-2.pdf

Nandini, W. (2018). Perkawinan anak di Indonesia mengkhawatirkan. Retrieved from https://katadata.co.id/ariayudhistira/infografik/5e9a55de4cd54/perkawinan-anak-di-indonesiamengkhawatirkan.

Lee-Rife, S., Malhotra, A., Warner, A., Glinski, A. M. (2012). What works to prevent child marriage: a review of the evidence. Studies in Family Planning, 43(4) pp. 287-303.

Littlejohn, S. W. \& Foss, K. A. (eds.) (2009). Encyclopedia of communication theory. California: Sage

Luhmann, N. (1995). Social Systems. Stanford, California: Stanford University Press.

Malhotra, A., Warner, A., McGonagle, A., \& Lee-Rife, S. (2011). Solutions to end teen marriage: What the evidence shows. ICRW.

Miles, M. B., Huberman, A. M., \& Saldana, J. (2014). Qualitative data analysis: a methods sourcebook. USA: Sage.

Mukson, M. (2013). Tradisi perkawinan usia dini di desa Tegaldowo. Jurnal Bimas Islam, 6(1).

Plan Asia. (2013). Teen marriage in Bangladesh, India, and Nepal. Bangkok: Plan Asia.

Rembang Ministry of Religion. (2018). Data pernikahan berbasis usia.

Rembang Ministry of Religion. (2019). Data pernikahan berbasis usia.

Ritzer, George. (2004). Teori sosiologi modern (trans.). Jakarta: Prenada Media.

Soy, Sue. (2006). The case study as a research method. Retrieved from http://www.gslis.utexas.edu/ ssoy/usesusers/l391d1b.htm.

Wahyuni, H. I., Partini, Sadasri, L. M. (2018). Dinamika isu pernikahan anak di Indonesia pada media baru. Iptek-kom, 20(2), pp. 183-198.

Watzlawick, P., Beavin, J. H, \& Jackson, D. D. (1967). Pragmatics of human communication: a study of interactional patterns, pathologies and paradoxes. New York: W. W. Norton \& Company.

Yin, Robert K. (2003). Case study research design and methods, ( $\left.3^{\text {rd }} \mathrm{Ed}\right)$. London: Sage Publications.

Yin, Robert K. (2012). Applications of case study research. USA: Sage.

\section{Acknowledgements}

The authors would like to thank the Directorate of Research and Community Service, the Directorate General of Research and Development, the Ministry of Research and Technology, and Higher Education for funding this research with the Leading Higher Education Basic Research scheme. Thanks are also extended to all parties involved in the research process: LPPM UGM, Religious Court, Office of Religious Affairs, Ministry of Religion, Javanese Christian Church, Central Statistics Bureau, Dukcapil, Community Section, Youth Groups and Parents Groups, PPKB Social Affairs, Muhammadiyah Youth, Ministry of Information and Telecommunication, and P2TP2A, as well as researchers and activists specialising in gender, decentralisation, community development, and teenagers' rights. Particular thanks are due to SPEK HAM, Unala, Rifka Annisa, PKBI, Harapan Fian Foundation, and the "Yes I Do" Alliance. 